Ceramic Sherd Assemblages from the Hawkins Bluff (41CS2), Snipes (41CS8), and 41CS44 Sites on the lower Sulphur River at Lake Wright Patman, Cass County, Texas

Timothy K. Perttula

Heritage Research Center, Stephen F. Austin State University

Follow this and additional works at: https://scholarworks.sfasu.edu/ita

Part of the American Material Culture Commons, Archaeological Anthropology Commons, Environmental Studies Commons, Other American Studies Commons, Other Arts and Humanities Commons, Other History of Art, Architecture, and Archaeology Commons, and the United States History Commons

Tell us how this article helped you.

This Article is brought to you for free and open access by the Center for Regional Heritage Research at SFA ScholarWorks. It has been accepted for inclusion in Index of Texas Archaeology: Open Access Gray Literature from the Lone Star State by an authorized editor of SFA ScholarWorks. For more information, please contact cdsscholarworks@sfasu.edu. 


\section{Ceramic Sherd Assemblages from the Hawkins Bluff (41CS2), Snipes (41CS8),}

and 41CS44 Sites on the lower Sulphur River at Lake Wright Patman, Cass County, Texas

Creative Commons License

(c) $(1)$ ( 8

This work is licensed under a Creative Commons Attribution-NonCommercial 4.0 International License 


\title{
Ceramic Sherd Assemblages from the Hawkins Bluff (41CS2), Snipes (41CS8), and 41CS44 Sites on the lower Sulphur River at Lake Wright Patman, Cass County, Texas
}

\author{
Timothy K. Perttula
}

\section{Introduction}

Many documented sites on the lower Sulphur River in the East Texas Pineywoods were occupied by Caddo peoples, and there are a number of such sites at Lake Wright Patman, including better known sites such as Knight's Bluff (41CS14) and Sherwin (41CS26) (Jelks 1961; Perttula 1998; Perttula et al. 1998). These sites appear to have been small villages with family cemeteries, occupied between ca. A.D. 1200-1400 (Perttula et al. 2009). In this article, I discuss the ceramic sherd assemblages from three less well-known Middle Caddo period occupations at other sites at Lake Wright Patman (Figure 1).

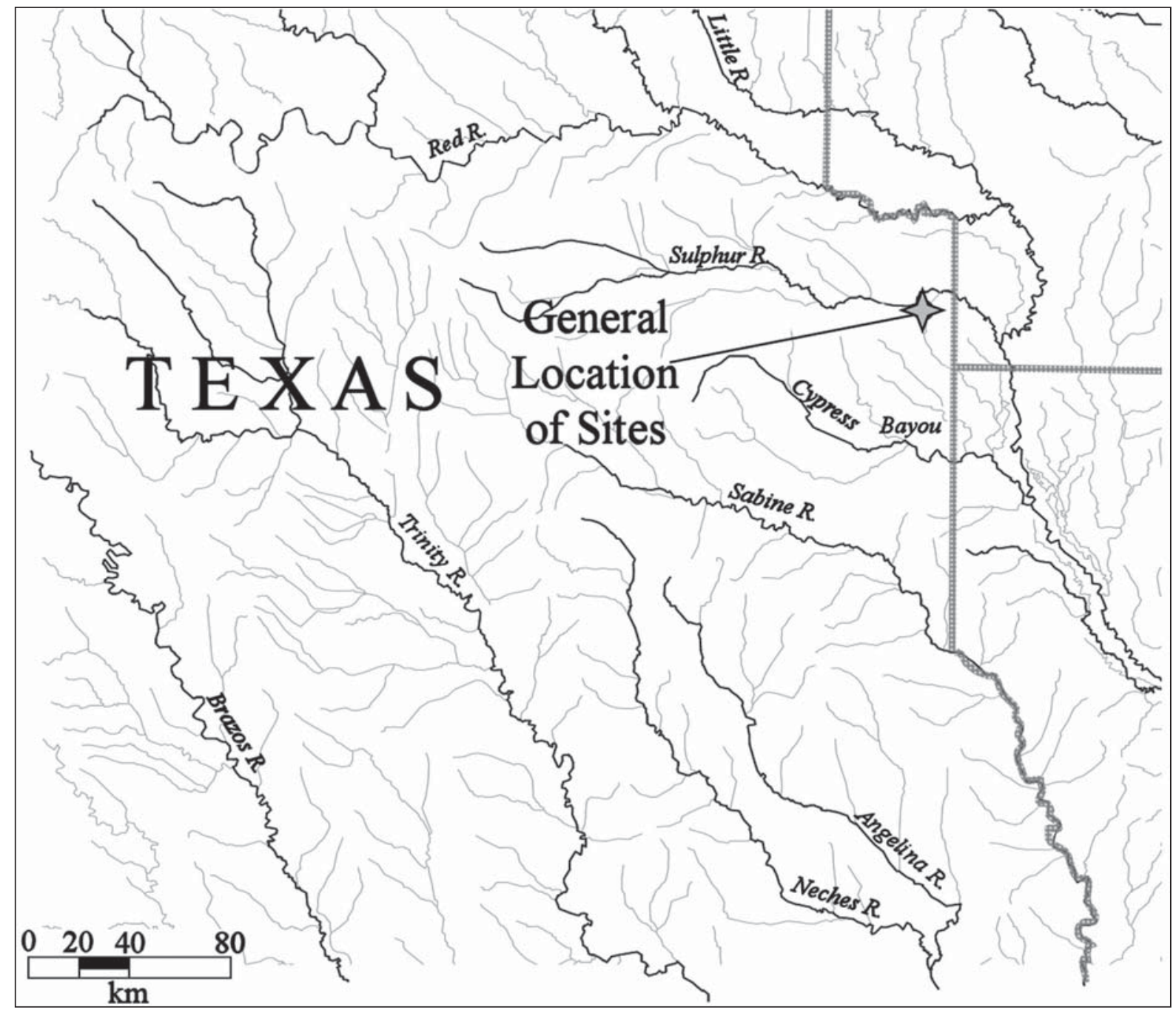

Figure 1. General location of the Hawkins Bluff, Snipes, and 41CS44 sites on the lower Sulphur River in East Texas. 


\section{Ceramic Sherd Assemblages}

The three sites under consideration in this article have ceramic sherd collections curated at the Texas Archeological Research Laboratory at The University of Texas at Austin. There are a total of 342 ceramic sherds in the collections from the three sites (between 72-159 sherds per site); 115 sherds are from decorated fine ware and utility ware vessels. A small number of the sherds from the Snipes site (41CS8) can be associated with the late Woodland component there (i.e., the sherds are from thick-walled Williams Plain vessels), but all three sites have ancestral Caddo ceramic sherd assemblages.

\section{Hawkins Bluff (41CS2)}

The Hawkins Bluff site covered about 5-10 acres of an upland and bluff landform (230-277 ft. amsl) overlooking the floodplain of the Sulphur River (now inundated by the waters of Lake Wright Patman). The ceramic sherd assemblage is a surface collection gathered during the 1949 River Basin Surveys (RBS) of the proposed reservoir.

The ceramic sherd assemblage has 72 rim, body, and base sherds from plain ware, fine ware, and utility ware vessels (Table 1). About 83 percent of the sherds are from grog-tempered vessels, and the remainder have crushed burned bone added to the paste; the proportion of bone-tempered sherd is highest in the fine wares (37.5 percent) (Table 1$)$.

Table 1. The ceramic sherd assemblage from the Hawkins Bluff site (41CS2).

\begin{tabular}{|c|c|c|c|c|c|c|}
\hline Ware & Rim & Body & Base & Grog temper & Bone temper & $\mathrm{N}$ \\
\hline Plain & - & 40 & 6 & 40 & 6 & 46 \\
\hline Fine & 2 & 6 & - & 5 & 3 & 8 \\
\hline Utility & 2 & 16 & - & 15 & 3 & 18 \\
\hline Totals & 4 & 62 & 6 & 60 & 12 & 72 \\
\hline
\end{tabular}

Of the decorated sherds, 69 percent are rim and body sherds from utility ware vessels, primarily jars (see Table 1). the few rim sherds are split equally between the two wares.

The fine ware sherds from the Hawkins Bluff site include those with engraved decorative elements as well as sherds from red-slipped vessels (Table 2). In fact, 25 percent of the fine ware sherds in the small assemblage are from red-slipped vessels. Red-slipped fine wares (bowls, carinated bowls, and an occasional bottle) are a common part of ancestral Caddo ceramic assemblages in several parts of East Texas, particularly assemblages that date to the Middle Caddo period (ca. A.D. 1200-1400) (Perttula 2015a:Figure 3). One of the engraved sherds from a carinated bowl has a red slip on both vessel surfaces as well as diagonal engraved lines.

Table 2. Ceramic decorative methods and elements in the fine and utility ware sherds from the Hawkins Bluff site (41CS2).

\begin{tabular}{llll}
\hline Decorative method/decorative element & Rim & Body & $\mathrm{N}$ \\
\hline
\end{tabular}

\section{Fine Ware}

Engraved

curvilinear engraved line and triangular hatched zones diagonal engraved lines and int./ext. red-slipped horizontal engraved lines horizontal lines and curvilinear hatched bracket element

$\begin{array}{lll}- & 1 & 1 \\ - & 1 & 1 \\ 1 * & - & 1 \\ 1 & - & 1\end{array}$


Table 2. Ceramic decorative methods and elements in the fine and utility ware sherds from the Hawkins Bluff site (41CS2), cont.

\begin{tabular}{llll}
\hline straight engraved line & - & 1 & 1 \\
vertical and diagonal opposed engraved lines & - & 1 & 1
\end{tabular}

\section{Red-Slipped}

int. and ext. red-slipped $-$

2

\section{Utility Ware}

Appliqued

straight appliqued fillet

$-$

1

1

\section{Brushed}

horizontal brushing marks

parallel brushing marks

$\begin{array}{lll}- & 1 & 1 \\ - & 1 & 1\end{array}$

\section{Brushed-Appliqued}

parallel brushed and parallel appliqued ridges

$-\quad 1$

1

Incised

parallel incised lines

straight incised line

$\begin{array}{lll}- & 2 & 2 \\ - & 1 & 1\end{array}$

\section{Incised-Punctated}

horizontal incised lines and adjacent tool punctated row incised triangle el. filled with rows of tool punctates

$\begin{array}{lll}- & 1 & 1 \\ - & 1 & 1\end{array}$

\section{Punctated}

\begin{tabular}{llll} 
fingernail punctated rows & 1 & 3 & 4 \\
tool punctated rows & 1 & 4 & 5 \\
\hline Totals & 4 & 22 & 26
\end{tabular}

*one rim also has an engraved lip line; el.=element

A horizontal engraved rim sherd from a grog-tempered vessel also has an engraved lip line (see Table 2). Other engraved sherds from the Hawkins Bluff site have a curvilinear element and triangular hatched zones (Figure 2a), vertical and diagonal opposed engraved lines on a carinated bowl rim panel (Figure 2b), and a large engraved bracket filled with opposed curvilinear engraved lines (Figure 2c). 


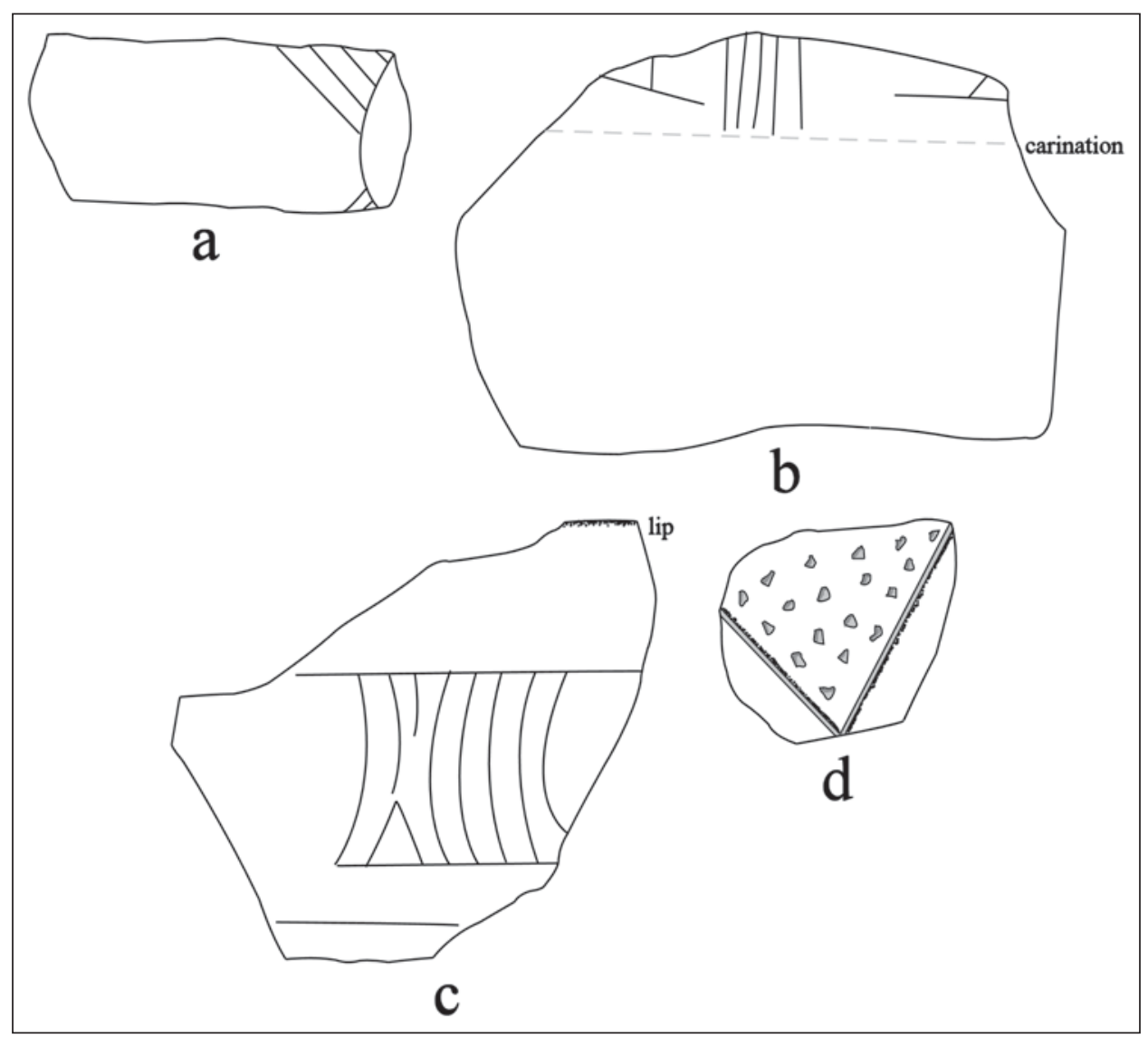

Figure 2. Selected decorative elements on sherds from the Hawkins Bluff site: a-c, engraved elements; $d$, incised-punctated elements.

The most common decorative elements on the utility ware sherds from the Hawkins Bluff site are rows of either fingernail or tool punctations (see Table 2); these comprise 50 percent of the utility wares and 33 percent of the decorated sherds from the site. Other decorative elements include incised lines $(n=3)$, appliqued fillets $(\mathrm{n}=1)$, sherds with brushing marks $(\mathrm{n}=2)$, sherds with brushing marks parallel to appliqued ridges $(\mathrm{n}=1)$, and sherds with incised-punctated elements $(n=2)$. One distinctive sherd has an incised triangle filled with rows of small triangular-shaped tool punctations (see Figure 2d).

\section{Snipes (41CS8)}

The Snipes site was excavated by the RBS in 1952 (Jelks 1961). The site was on a low sandy ridge about $1.6 \mathrm{~km}$ south of the Sulphur River, and had midden deposits as well as 12 or more burial features, nine of which were excavated by the RBS team. The Snipes site has both Woodland and ancestral Caddo components with associated ceramic wares (see Jelks 1961; Story 1990; Ellis 2013), including plain bowls with thin walls and a barrel-shaped Coles Creek Incised, var. Stoner (estimated to date from ca. A.D. 550-700, see Brown [1998:8, 53]) bowl with a single overhanging incised line and an incised lip line from several of the burial features.

The ceramic sherd collection discussed in this collection was gathered during the 1949 RBS survey investigations. It includes 159 sherds from plain ware, fine ware, and utility ware vessels, and about 11 percent are from thick-walled and grog-tempered Williams Plain vessels (Table 3). Among the other sherds, about 10 percent are from vessels manufactured with burned bone temper, and the remainder are from grog-tempered vessels. The highest proportion of bone-tempered sherds occur among the fine wares ( 20 percent). 
Table 3. The ceramic sherd assemblage from the Snipes site (41CS8).

\begin{tabular}{lllllll}
\hline Ware & Rim & Body & Base & Grog temper & Bone temper & N \\
\hline Plain & 5 & 71 & 6 & 72 & 10 & 82 \\
Williams & - & 10 & 7 & 17 & - & 17 \\
$\quad$ Plain & 2 & 8 & - & 8 & 2 & 10 \\
Fine & 6 & 44 & - & 48 & 2 & 50 \\
Utility & 13 & 133 & 13 & 145 & 14 & 159 \\
\hline Totals & & & & &
\end{tabular}

The decorated ceramic sherds from this collection from the Snipes site include eight rim sherds and 55 body sherds (see Table 3). About 83 percent of the decorated sherds are from utility wares. Most of the decorated rim sherds ( 75 percent) in the assemblage are from utility ware vessels.

All of the fine wares from the Snipes site in the 1949 surface collection are from engraved vessels, probably all carinated bowls (Table 4). Rim sherds have sets of horizontal engraved lines, there are other sherds with hatched and cross-hatched zones, and one sherd has both diagonal and triangular hatched zones (Figure 3a). One engraved sherd in the assemblage has horizontal engraved lines with open pendant triangle elements (Figure 3b).

Table 4. Ceramic decorative methods and elements in the fine and utility ware sherds from the Snipes site (41CS8).

\begin{tabular}{llll}
\hline Decorative method/decorative element & Rim & Body & $N$ \\
\hline
\end{tabular}

Fine Ware

Engraved

curvilinear engraved line

curvilinear zone filled with cross-hatched lines

diagonal engraved lines

horizontal engraved lines

horizontal engraved lines and open pendant triangles

horizontal-vertical lines, and diagonal and triangular

hatched zones

straight engraved line

$\begin{array}{lll}- & 1 & 1 \\ - & 1 & 1 \\ - & 1 & 1 \\ 2 & 2 & 4 \\ - & 1 & 1 \\ - & 1 & 1 \\ - & 1 & 1\end{array}$

\section{Utility Ware}

Brushed

horizontal brushing marks

parallel brushing marks

$-2$

\section{Brushed-Appliqued}

curvilinear appliqued fillet and parallel and diagonal

opposed brushing marks 
Table 4. Ceramic decorative methods and elements in the fine and utility ware sherds from the Snipes site (41CS8), cont.

\section{Brushed-Incised-Punctated}

horizontal tool punctated row above diagonal brushing marks and opposed sets of diagonal incised lines

\section{Brushed-Punctated}

diagonal and vertical brushing marks opposite a tool punctated row at rim-body juncture

parallel brushing marks and tool punctated row through the brushing

\section{Incised}

diagonal opposed incised lines

horizontal incised lines, multiple

opposed incised lines

parallel incised lines

straight incised line

$\begin{array}{lll}- & 1 & 1 \\ 4 & - & 4 \\ - & 1 & 1 \\ - & 27 & 27 \\ - & 1 & 1\end{array}$

\section{Incised-Punctated}

diagonal opposed incised lines and row of linear tool punctations

\section{Punctated}

single fingernail punctation

Totals

\begin{tabular}{lll}
- & 1 & 1 \\
\hline 8 & 52 & 60 \\
\hline
\end{tabular}

Sherds from utility ware vessels with incised line decorative elements are most common in the Snipes site sherds, as they account for 56.7 percent of all the decorated sherds in the assemblage and 68 percent of the utility ware sherds (see Table 8). These sherds indicate that rims commonly had sets of horizontal incised lines as well as simple geometric elements on the vessel body. There are very few sherds from the Snipes site that have incised-punctated (see Figure 3c) or punctated decorative elements. Much more common are sherds from vessels with brushed, brushed-appliqued (see Figure 3d), brushed-punctated (see Figure 3e), and brushed-incised-punctated (see Figure 3f) decorative elements on rim and/or vessel body. These sherds are likely from Pease Brushed-Incised vessels (see Suhm and Jelks 1962:Plate 60).

\section{$41 C S 44$}

This Caddo site is on a low alluvial landform in the Sulphur River floodplain; it is exposed now as a narrow island (220-221 ft. amsl) in the Lake Wright Patman flood pool. When it was recorded by Briggs and Malone (1970), they noted that the site had a preserved midden deposit.

The ceramic assemblage at the site consists of 111 sherds from plain ware, utility ware, and fine ware vessels (Table 5). Almost 95 percent of the sherds are from grog-tempered vessels, and only a few of the plain ware sherds are from bone-tempered vessels. 


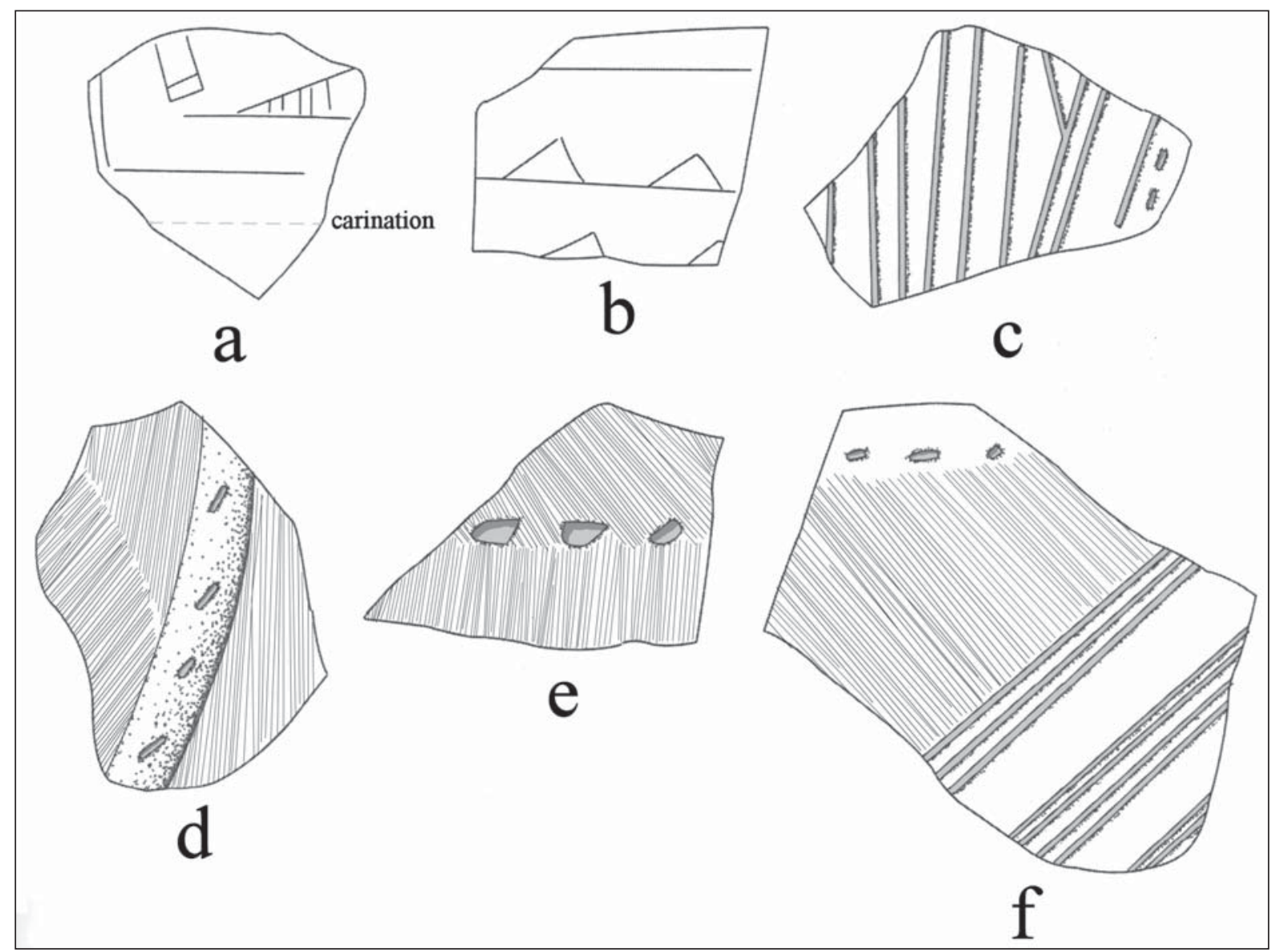

Figure 3. Selected decorative elements in the sherds from the Snipes site (41CS8): a-b, engraved; c, incisedpunctated; d, brushed-appliqued; e, brushed-punctated; f, brushed-incised-punctated.

Table 5. The ceramic sherd assemblage from $41 \mathrm{CS} 44$.

\begin{tabular}{lllllll}
\hline Ware & Rim & Body & Base & Grog temper & Bone temper & N \\
\hline Plain & 1 & 74 & 8 & 77 & 6 & 83 \\
Fine & 3 & 1 & - & 4 & - & 4 \\
Utility & 6 & 18 & - & 24 & - & 24 \\
\hline Totals & 10 & 93 & 8 & 105 & 6 & 111 \\
\hline
\end{tabular}

Utility wares comprise 85.7 percent of the decorated sherds $(n=28)$ from 41CS44 as well as 66.7 percent of the decorated rim sherds (see Table 5). The fine wares from the site are engraved vessels. Two rim sherds have sets of horizontal engraved lines, and another has horizontal, vertical, and curvilinear engraved elements (Table 6 and Figure 4a). 
Table 6. Ceramic decorative methods and elements in the fine and utility ware sherds from $41 \mathrm{CS} 44$.

\section{Decorative
Fine Ware
Engraved}

horizontal engraved lines

horizontal, vertical, and curvilinear engraved lines

parallel engraved lines

Rim Body N

Utility Ware

Brushed-Punctated

diagonal opposed brushing marks and fingernail

$-1$

punctated row at rim-body juncture; vertical brushed

body

Incised

curvilinear incised line

single horizontal incised line

horizontal incised lines, multiple

parallel incised lines

straight incised line

$\begin{array}{lll}2 & - & 2 \\ 1 & - & 1 \\ - & 1 & 1\end{array}$

\section{Incised-Punctated}

curvilinear hatched incised triangle and curvilinear

and circular incised element filled with tool punctates

diagonal incised lines with circular punctations

between lines and zone of circular punctates

horizontal and diagonal opposed incised lines with

triangle-shaped area filled with tool punctates

\section{Punctated}

fingernail punctated rows

linear punctated horizontal rows

linear punctated horizontal and vertical rows

linear punctated parallel rows

Totals

9

\begin{tabular}{lll}
- & 3 & 3 \\
1 & - & 1 \\
- & 1 & 1 \\
- & 1 & 1 \\
\hline 9 & 19 & 28
\end{tabular}

The utility wares from 41CS44 are dominated by sherds with incised decorative elements ( 50 percent of all the decorated sherds and 58.3 percent of all the decorated sherds from the site), including rims with horizontal incised lines and simple geometric elements on the vessel body (see Table 6). Also common are sherds with punctated elements (21.4 percent of the decorated sherds), particularly several sherds with linear punctated decorations; these are likely from Sinner Linear Punctated vessels (see Suhm and Jelks 1962:Plate 72). 


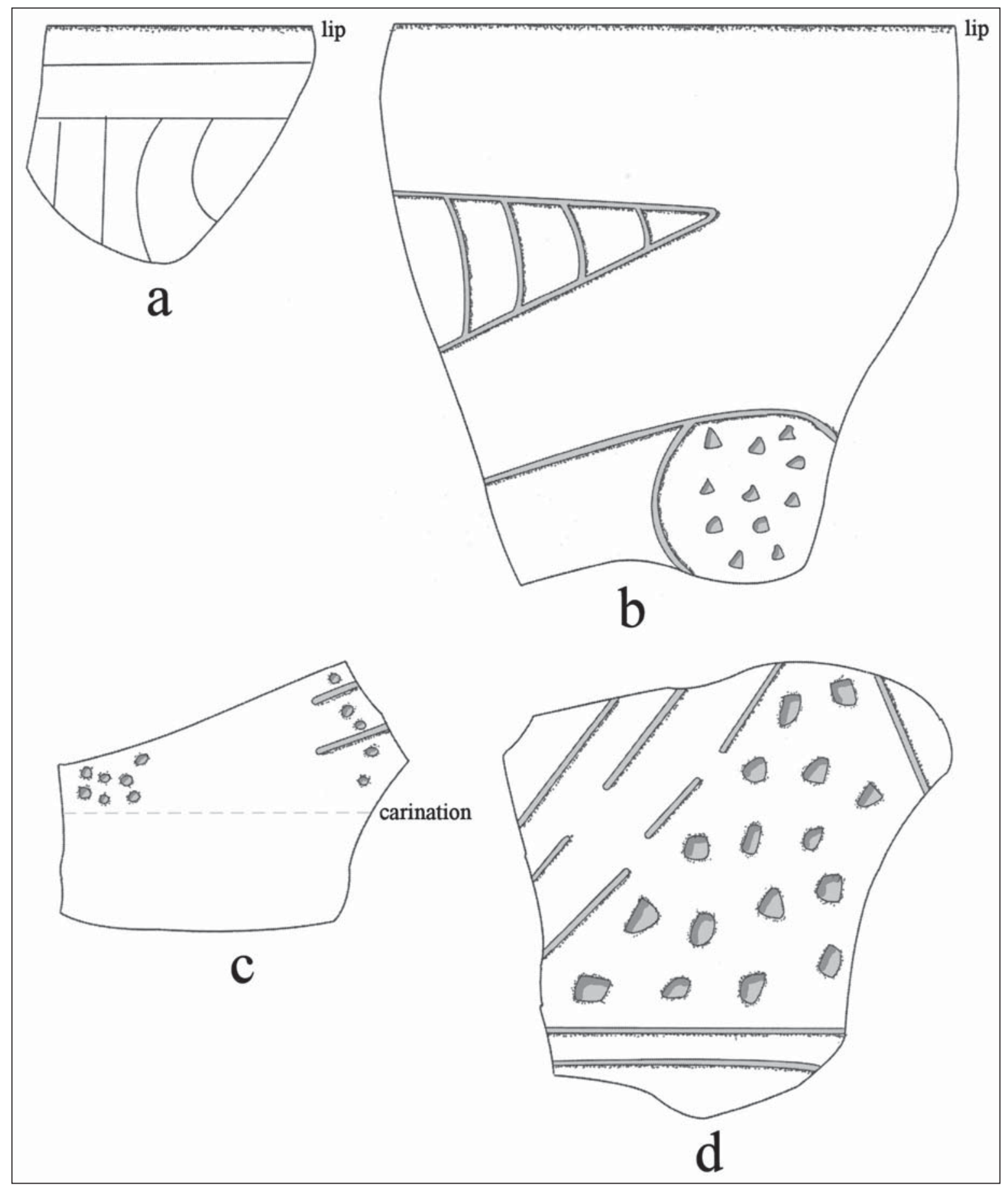

Figure 4. Decorative elements on selected sherds from 41CS44: a, engraved; b-d, incised-punctated rim and body sherds.

Sherds with incised-punctated decorative elements are also represented at 41CS44, accounting for 10.7 percent of the decorated sherds from the site. One rim sherd with a circle element filled with triangular-shaped tool punctations may be from a Crockett Curvilinear Incised vessel (see Figure 4b). Another sherd has diagonal incised lines with circular punctations between lines and a zone of circular punctates (see Figure 4c), and a large body sherd has horizontal and diagonal opposed incised lines with a triangle-shaped area filled with tool punctates (see Figure 4d). 


\section{Summary and Conclusions}

This article concerns the analysis of the ceramic sherd assemblages from three ancestral Caddo sites at Lake Wright Patman: Hawkins Bluff (4CC2), Snipes (41CS8), and 41CS44. The ceramic sherd assemblages are curated at the Texas Archeological Research Laboratory at The University of Texas at Austin. Also discussed in this section are the ceramics from a generally contemporaneous ancestral Caddo occupation at the Armstrong Landing site (41CS37) (Perttula 2015b).

Other than the Williams Plain sherds from the Snipes site, the overall character of the sherd assemblagesgathered during 1949 and 1970 archaeological surveys of the Lake Wright Patman flood pool - suggests that each has ancestral Caddo occupations that took place in the Middle Caddo period (dating from ca. A.D. 1200-1400). The sherds are from assemblages where the majority of the vessels were grog-tempered: only between 5.9-16.7 percent of the sherds at the sites have bone temper (Table 7). The proportion of brushed sherds in the assemblages range from 3.6-23.4 percent.

Table 7. Ceramic sherd comparisons.

\begin{tabular}{|c|c|c|c|c|}
\hline Attributes & $41 \mathrm{CS} 44$ & $41 \mathrm{CS} 2$ & $41 \mathrm{CS} 37$ & $41 \mathrm{CS} 8$ \\
\hline Percent bone temper & 5.9 & 16.7 & 10.5 & 10.0 \\
\hline Percent brushed & 3.6 & 11.1 & 18.9 & 23.4 \\
\hline Brushed sherds are common & & & + & + \\
\hline Brushed-incised sherds are common & & & + & \\
\hline Brushed-punctated sherds are common & & & & + \\
\hline Incised-punctated sherds are common & + & & & \\
\hline Linear punctated sherds are common & + & & & \\
\hline Fingernail and tool punctated sherds are common & & + & & \\
\hline Appliqued and appliqued-incised sherds are common & & + & + & \\
\hline Engraved sherds are common & & & + & + \\
\hline Engraved-punctated sherds are common & & & + & \\
\hline Red-slipped sherds are common & & + & & \\
\hline
\end{tabular}

$+=$ presence in common amounts

Sherds from brushed utility ware vessels, particularly jars, are a distinctive characteristic of both Middle, Late, and Historic Caddo sites in much of East Texas. It also appears to be the case that the relative proportions of brushed utility wares increase through time in those areas where brushed vessels were made and used, such that sherds with brushing marks may comprise as much as 90 percent of all the decorated sherds in some post-A.D. 1400 East Texas ceramic assemblages (see Perttula 2015a). In the case of the Lake Wright Patman ceramic assemblages discussed herein, the fact that brushed sherds are present in each assemblage strongly suggests that they date after ca. A.D. 1200-1250, when brushed vessels began to be made in East Texas. The differences in the proportion of brushed sherds in the decorated sherd assemblages (see Table 7) suggests that the oldest of these ancestral Caddo occupations was at 41CS44, followed by Hawkins Bluff (41CS2), Armstrong Landing (41CS37), and Snipes (41CS8), with Snipes being the youngest of these Middle Caddo period assemblages. The decorated ceramic sherd assemblage from the nearby Knight's Bluff site (41CS14) is quite similar to the assemblages from these other Lake Wright Patman Caddo sites.

Sherds with brushed-incised and brushed-punctated decorative elements-from Pease Brushed-Incised vessels - are most common in the latter of these Middle Caddo assemblages, as are sherds from engraved and engraved-punctated vessels (see Table 7). Red-slipped sherds are most common in the earlier of the Middle Caddo 
period sherd assemblages. The earlier of the Middle Caddo period assemblages at Lake Wright Patman also have higher proportions of linear tool punctated, fingernail punctated, and tool punctated decorative elements. Sherds from Crockett Curvilinear Incised or Pennington Punctated-Incised vessels occur in the earlier Middle Caddo period assemblages from 41CS44 and the Hawkins Bluff site (41CS2), suggesting their occupations predate ca. A.D. 1300. The other two Middle Caddo sites may have primarily been occupied after ca. A.D. 1300.

\section{Acknowledgments}

Lance Trask prepared the figures in this article. Thanks also to Marybeth Tomka at the Texas Archeological Research Laboratory at The University of Texas at Austin for facilitating access to the collections from these four Lake Wright Patman Caddo sites.

\section{References Cited}

Briggs, A. K. and J. Malone

1970 Texarkana Reservoir Enlargement. Archeological Survey Report No. 7. Texas Historical Survey Committee, Austin.

Ellis, L. W.

2013 Woodland Ceramics in East Texas and a Case Study of Mill Creek Culture Ceramics. Bulletin of the Texas Archeological Society 84:137-180.

Jelks, E. B.

1961 Excavations at Texarkana Reservoir, Sulphur River, Texas. River Basin Survey Papers No. 21. Bureau of American Ethnology, Smithsonian Institution, Washington, D.C.

Perttula, T. K.

1998 Caddo Ceramics from the Middle Caddoan Period Knight's Bluff Site (41CS14), Cass County, Texas. Caddoan Archeology 8(4):11-19.

2015a East Texas Caddo Ceramic Sherd Database. Journal of Northeast Texas Archaeology 51:1-46.

2015b Armstrong Landing Site (41CS37): An Ancestral Caddo Site on the Sulphur River, Cass County, Texas. Journal of Northeast Texas Archaeology 54:55-62.

Perttula, T. K., R. Cast, B. Gonzalez, and B. Nelson

2009 Documentation of Unassociated and Culturally Unidentifiable Funerary Objects in the U.S. Army Corps of Engineers, Fort Worth District Collections Housed at the Texas Archeological Research Laboratory at the University of Texas at Austin. Special Publication No. 13. Friends of Northeast Texas Archaeology, Pittsburg and Austin.

Perttula, T. K., D. J. Prikryl, and B. Nelson

1998 Archeological Evaluation of a Proposed Sewer Line in the Knight's Bluff Campground at Atlanta State Park, and Delineation of the Knight's Bluff Site (41CS14) Cemetery/Midden Areas. In 1997 Annual Report to the Texas Historical Commission, by Texas Parks and Wildlife Department, pp. 339-385. Cultural Resources Program, Texas Parks and Wildlife Department, Austin.

Story, D. A.

1990 Cultural History of the Native Americans. In The Archeology and Bioarcheology of the Gulf Coastal Plain, by D. A. Story, J. A Guy, B. A. Burnett, M. D. Freeman, J. C. Rose, D. G. Steele, B. W. Olive, and K. J. Reinhard, pp. 163-366. Research Series No. 38. 2 Vols. Arkansas Archeological Survey, Fayetteville.

Suhm, D. A. and E. B. Jelks (editors)

1962 Handbook of Texas Archeology: Type Descriptions. Special Publication No. 1, Texas Archeological Society, and Bulletin No. 4, Texas Memorial Museum, Austin. Reprinted in 2009, Gustav's Library, Davenport, Iowa. 